\title{
PEMANFAATAN LIMBAH JELANTAH SEBAGAI PROGRAM PENGEMBANGAN PRODUK UMKM DI WILAYAH KAMPUNG KOTA
}

\author{
Samsu Hendra Siwi ${ }^{1}$, Fermanto Lianto ${ }^{2}$ dan Joni Chin ${ }^{3}$ \\ ${ }^{1}$ Jurusan Arsitektur, Universitas Tarumanagara Jakarta \\ Email: samsus@ft.untar.ac.id \\ 2 Jurusan Arsitektur, Universitas Tarumanagara Jakarta \\ Email: fermantol@ft.untar.ac.id \\ ${ }^{3}$ Jurusan Arsitektur, Universitas Tarumanagara Jakarta \\ Email: jonic@ft.untar.ac.id
}

\begin{abstract}
"Jelantah" as household waste produced from kitchen activities is used frying oil that has been used several times. This used cooking oil is harmful to health because it already contains carcinogens. Carcinogens are substances that can trigger cancer. Body cells will be triggered to become cancer cells. Then, how to handle this used cooking oil? Many residents throw used cooking oil into waterways or sewers. This disposal will undoubtedly have an impact. The impact of environmental pollution, especially on water and soil, is being concentrated by environmentalists. The " jelantahization" movement is one answer to the solution to this problem. Jelantahization is a RW 11 program so that residents are aware of the health and environmental hazards of used cooking oil. The cooking program is carried out from upstream to downstream, meaning from campaigns, mapping the distribution of residents who have collected used cooking oil, deposited used cooking oil, and made products from used cooking oil., the use of soap produced from used cooking oil to the packaging of soap from used cooking oil and its marketing. The partner's problem is making a planned, structured, and measurable program whose outcome can be seen for its success. Partners also want assistance on the progress of the implementation of waste cooking oil utilization. This program is carried out together in RW 11, Pekayon Jaya Village, South Bekasi. Partner locations are residential areas that can be classified as urban villages. This PKM is carried out for program development and implementation assistance to obtain measurable results in quantity and quality. The stages were carried out from socialization to residents about the dangers of used cooking oil, both health and environmental hazards, awareness socialization of used cooking waste collection, training on the soap making process, packing. This PKM is creating an integrated MIJEL (cooking oil) banking system for all residents of $R W 11$, along with training on its derivative products, namely making soap and aromatherapy candles.
\end{abstract}

Keywords: Utilization of Cooking Oil, Kampung Kota

\begin{abstract}
ABSTRAK
Minyak jelantah yaitu bekas minyak penggorengan yang sudah beberapa kali dipakai. Minyak jelantah ini berbahaya bagi kesehatan karena sudah mengandung karsinogen. Karsinogen adalah zat yang dapat memicu kanker. Sel-sel tubuh akan dipicu menjadi sel-sel kanker. Kemudian, bagaimana penanganan minyak jelantah ini? Banyak warga yang membuang minyak jelantah ke saluran air ataupun ke selokan. Pembuangan ini tentu akan menjadikan dampak. Dampak pencemaran lingkungan terutama pada air dan tanah menjadi konsentrasi oleh pemerhati lingkungan. Gerakan jelantahisasi merupakan satu jawaban untuk solusi permasalahan ini. Jelantahisasi merupakan program RW 11 agar warga sadar akan bahaya kesehatan dan bahaya lingkungan pada minyak jelantah ini. Program Jelantahisasi dilakukan dari hulu ke hilir, artinya dari kampanye, pemetaan sebaran warga yang sudah melakukan pengumpulan minyak jelantah, setor minyak jelantah, pembuatan produk dari minyak jelantah, pemakaian sabun hasil dari minyak jelantah, hingga pengemasan sabun dari minyak jelantah serta pemasarannya. Permasalahan mitra adalah pada pembuatan program yang terencana, terstruktur dan terukur yang outcomenya dapat terlihat jelas untuk keberhasilannya. Mitra juga menginginkan pendampingan progres pelaksanaan Pemanfaatan limbah minyak jelantah. Program ini dilakukan bersama-sama se wilayah RW 11, Kelurahan Pekayon Jaya, Bekasi Selatan. Lokasi mitra merupakan wilayah perumahan yang dapat digolongkan sebagai kampung kota. PKM ini dilakukan untuk pembuatan program dan pendampingan pelaksanaan hingga mendapatkan hasil yang terukur secara kuantitas dan kualitas. Tahapan-tahapan dilakukan dari sosialisasi ke warga tentang bahaya jelantah baik bahaya kesehatan dan lingkungan, sosialisasi kesadaran pengumpulan limbah jelantah, pelatihan proses pembuatan sabun, packing. Hasil dari PKM ini berupa pembuatan sistem bank MIJEL(Minyak Jelantah) secara terpadu seluruh warga RW 11 beserta pelatihan produk turunannya yaitu pembuatan sabun dan lilin aroma terapi.
\end{abstract}

Kata kunci: Pemanfaatan Minyak Jelantah, Kampung Kota 


\section{PENDAHULUAN}

PKM jelantahisasi ini merupakan program lanjutan dari program PKM terdahulu dengan tujuan perbaikan kualitas lingkungan di Perumahan Pondok Pekayon Indah RW 11, Kelurahan Pekayon Jaya, Bekasi Selatan. Dari ketiga program yang akan dilakukan di RW 11 ini, mitra meminta bantuan berupa pembuatan rencana kerja secara bertahap, pelaksanaan enam bulan ke depan hingga pendampingan sebagai program berkelanjutan.

Pengabdian Kepada Masyarakat ini merupakan kelanjutan dari PKM terdahulu dengan surat Perjanjian Pelaksanaan Pengabdian Kepada Masyarakat Periode II Tahun Anggaran 2020 Nomor: 1551-Int-KLPPM/UNTAR/XI/2020" dengan judul "Kelorisasi, Telangisasi dan Pemanfaatan Limbah Jelantah Sebagai Program Pengembangan Produk UMKM Dalam Wilayah Kampung Kota". PKM ini dilakukan di wilayah RW 11, Kelurahan Pekayon Jaya Kecamatan Bekasi Selatan, Kota Bekasi. RW 11 dengan 4 RT berpenduduk sekitar 550 orang. Kesadaran untuk meningkatkan kualitas lingkungan telah dilakukan oleh RW 11.

Profil warga RW 11 didominasi warga usia pensiun (sekitar 56 ke atas) sehingga aktivitas dan waktu luang yang mereka berbeda dengan warga usia produktif atau di bawah 56 tahun. Penduduk dengan rata-rata manula mempunyai waktu yang relatif banyak daripada usia muda. Banyaknya waktu luang dan keinginan untuk hidup sehat baik secara jasmani dan rohani merupakan keinginan bersama warga RW 11. Kesadaran untuk hidup sehat di lingkungan sehat inilah sebagai potensi warga yang bisa dikembangkan. Banyak kegiatan yang dilakukan warga agar terwujudnya citacita bersama mereka yaitu hidup sehat lingkungan sehat. Lokasi RW 11 merupakan perumahan developer di tengah jantung kota Bekasi, sehingga dapat dikatakan sebagai kampung kota.

Prospek program ini sangatlah besar mengingat jumlah warga pemakai minyak goreng tiap harinya. Bila dihitung jumlah keluarga di 4 RT ini setiap harinya mengkonsumsi minyak goreng untuk memasak, maka bila dikumpulkan akan mencapai jumlah yang banyak. Penyadaran dan kemauan untuk mengumpulkan minyak jelantah serta tindakan untuk tidak membuang jelantah di selokan merupakan program tersendiri yang secara berkesinambungan akan dilakukan secara terus menerus. Pemahaman serta pelatihan pemanfaatan jelantah untuk sabun merupakan kegiatan yang dicanangkan oleh RW 11 sebagai langkah inovasi di samping Telangisasi dan Kelorisasi. Ketiganya akan bersinergi dalam program. Pewarnaan sabun pun bisa dilakukan dengan kelor dan telang.

Di setiap keluarga, pemakaian minyak goreng untuk memasak makanan hampir tiap hari dilakukan. Pemakaian minyak goreng untuk keperluan rumah tangga hampir 0,3 lt per hari (untuk menggoreng lauk, kerupuk, menumis sayuran dan lain-lain). Pemakaian minyak goreng ini kemudian menghasilkan minyak bekas sebagai limbah dari kegiatan keperluan rumah tangga tersebut. Beberapa orang tidak memahami bagaimana memperlakukan minyak goreng bekas ini. Karena ketidakpahaman tentang bagaimana memperlakukan minyak bekas ini, sebagian orang masih menggunakannya untuk menggoreng atau mengolah makanan lagi dan sebagian orang membuangnya di aliran air atau selokan. Kedua tindakan ini sangat berbahaya yaitu bahaya terhadap kesehatan dan lingkungan.

Pemakaian minyak jelantah untuk mengolah makanan sangat berbahaya untuk kesehatan. Kandungan karsinogen di dalam minyak jelantah karena minyak yang dipanaskan berulang-ulang membahayakan kesehatan manusia. Beberapa penyakit yang dapat ditimbulkan karena mengkonsumsi minyak jelantah adalah obesitas, resiko kanker, kolesterol tinggi, diabetes gestasional pada wanita hamil dan tenggorokan gatal (Angie, 2019). 
Karena kurang pengetahuan tentang bahaya minyak jelantah bila dipakai berulang-ulang untuk memasak makanan, banyak orang masih memakainya. Pemakaian minyak jelantah yang berulangulang akan menjadikan gugusan kimia dari minyak meningkat menjadi gugus radikal peroksida. Radikal Peroksida ini akan mengikat oksigen sehingga menjadikan oksidasi di jaringan tubuh. Ini akan sangat berbahaya bagi kesehatan manusia (Kenneth \& Heyes, 2007).

Penggunaan minyak jelantah sehari-hari dapat menyebabkan kerusakan oksidatif (Thadeus, 2015). Lebih lanjut dijelaskan penggunaan minyak jelantah dalam rumah tangga umumnya menghasilkan peroksida 20-40 meq/kg. Hal ini menyebabkan kerusakan oksidatif, merangsang proses peradangan hati, perlemakan hati atau steatosis dan menyebabkan kerusakan oksidatif DNA (Thadeus, 2015).

Minyak jelantah adalah minyak goreng bekas menggoreng yang sudah dipakai beberapa kali. Jelantah dari minyak ini bila sudah kotor, hitam dan bau sering dibuang. Namun sebagian orang mengolah minyak jelantah ini diolah dengan dijernihkan kembali untuk menjadi minyak goreng lagi dengan harga yang lebih murah. Hal ini tentu memberikan dampak buruk pada kesehatan.

Sesungguhnya, minyak jelantah ini masih bisa dimanfaatkan dengan tidak membahayakan kesehatan dan tidak mencemari lingkungan. Di atas sudah dijelaskan bahaya minyak jelantah bagi kesehatan manusia. Di samping itu menimbulkan permasalahan kesehatan tubuh, minyak jelantah juga sangat bahaya dan memberikan dampak lingkungan. Masalah yang dihadapi jika limbah minyak goreng dibuang secara sembarangan ke lingkungan dapat menyebabkan pencemaran bagi lingkungan. Limbah minyak goreng/jelantah yang dibuang ke perairan dapat menyebabkan rusaknya ekosistem perairan. Hal ini disebabkan tertutupnya permukaan air dengan lapisan minyak sehingga sinar matahari tidak dapat masuk ke perairan, akibatnya biota-biota perairan mengalami kematian yang akhirnya akan mengganggu ekosistem perairan tersebut.

Minyak Jelantah masih dapat dimanfaatkan tanpa membahayakan kesehatan dan ekosistem. Pembuatan sabun dan biodiesel merupakan solusi yang jitu untuk memanfaatkan jelantah ini. Bila dilihat masyarakat pemakai minyak goreng adalah hampir seluruh keluarga menggunakannya, maka dapat disimpulkan pemakaian minyak goreng dan jelantah yang dihasilkan sangat besar. Kalkulasi perhitungan ini belum termasuk restoran, hotel, warung makan dan penjual gorengan kaki lima dan sebagainya yang mana dapat disimpulkan pemakaian minyak goreng dan jelantah yang dihasilkan sangat besar. Oleh karena itu, pengolahan minyak jelantah dengan pemanfaatan tanpa merusak kesehatan dan lingkungan sangat penting.

Pengolahan minyak jelantah menjadi bahan utama sabun merupakan solusi jitu untuk penyelamatan lingkungan dari pencemaran terutama pencemaran air dan tanah. Minyak jelantah dengan kandungan trigliserida menjadi bahan baku alternatif untuk pembuatan sabun. Minyak jelantah biasanya bau (karena bekas aroma yang digoreng). Karbon aktif dan bubuk kopi dapat menghilangkan bau tersebut (Riyanta \& Nurniswati, 2017). Proses ini penting sebagai tahap awal setelah pengumpulan minyak jelantah untuk menghilangkan bau yang dikandung minyak jelantah sebelumnya. Setelah tahap penghilangan bau (butuh beberapa waktu) kemudian tahap proses penyaringan dan pengolahan. Perlu diingat, proses ini membutuhkan ketelitian takaran dan bahanbahan tambahan. Keberhasilan hasil sabun inipun ditentukan oleh cara dan jumlah adukan (Bidilah et al., 2017).

Program Pemanfaatan Limbah Minyak Jelantah dijalankan oleh warga RW 11. Peta Wilayah RW 11 Pondok Pekayon Indah Bekasi Selatan dapat dilihat pada Gambar 1. Program ini dibuat dari perencanaan hingga luaran dengan target capaian yang dapat diukur tingkat keberhasilannya. Mitra 
mengajukan permohonan bantuan pembuatan program pemanfaatan limbah minyak jelantah dari hulu hingga hilir yang artinya dari yang semula hanya sporadis (beberapa orang warga) menjadi program bersama, terschedule dalam setiap kegiatannya. Dengan demikian program ini bisa merata ke seluruh warga. Program ini merupakan program terpadu dari setiap warga masyarakat beserta perangkat aparaturnya (RT dan RW) yang dapat dirasakan manfaatnya oleh seluruh warga.

\section{Gambar 1}

Peta Wilayah RW 11 Pondok Pekayon Indah Bekasi Selatan (KBA Pekayon, 2020)

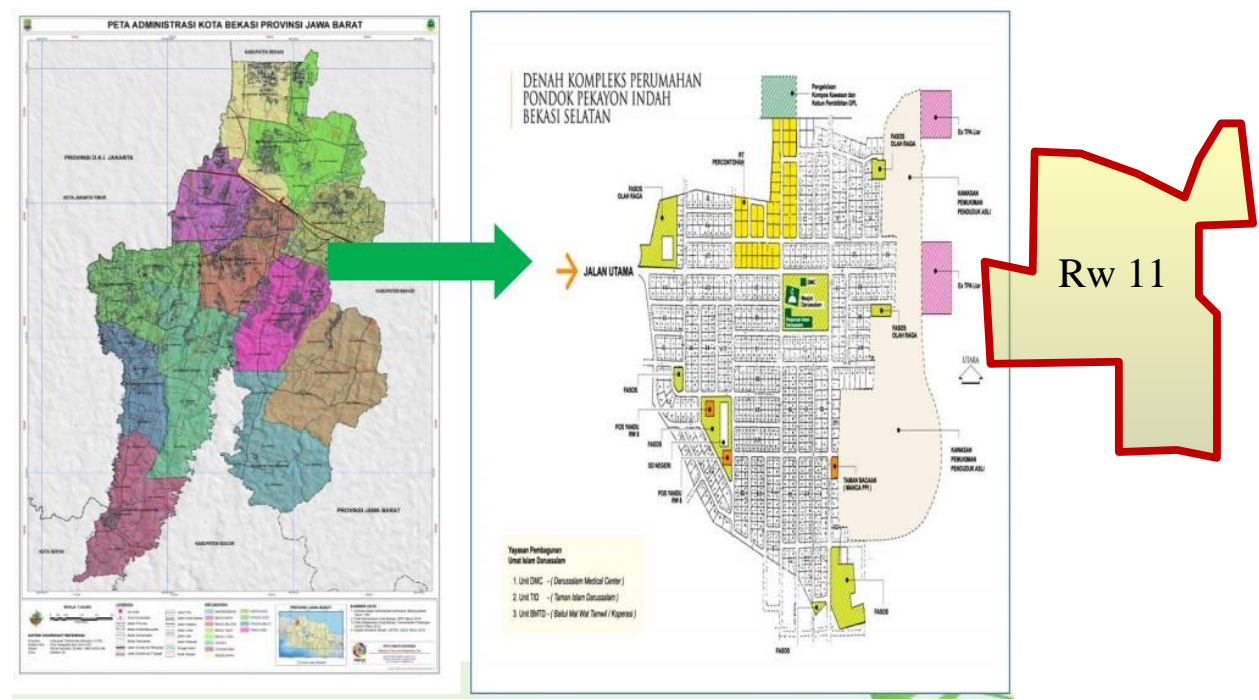

Pendampingan dalam pelaksanaan program juga diperlukan agar semua yang sudah diprogramkan dapat dilaksanakan dan mendapatkan hasil seperti yang diharapkan. Untuk menjawab permasalahan mitra ini, Tim memberikan ide/gagasan tentang langkah-langkah program serta schedule kerja yang dilaksanakan oleh Tim serta warga RW 11 dan pendampingan dalam pelaksanaannya.

Kegiatan PKM ini merupakan kelanjutan dari program terdahulu yaitu Telangisasi dan Kelorisasi berlokasi di RW 11 Kelurahan Pekayon Jaya, Bekasi Selatan. Ketiganya merupakan program lingkungan dengan titik berat pada penanggulangan pencemaran lingkungan dan penghijauan. Program ini sangat penting untuk meningkatkan kualitas lingkungan, terlebih lagi lingkungan di perkotaan dengan keterbatasan lahan. Program ini juga terkait dengan manajemen pengelolaan manusia (masyarakat), ekonomi dan perubahan perilaku manusia (masyarakat) pada lingkungannya. Perubahan perilaku manusia (masyarakat) lingkungan diharapkan dapat menjadi habit (mendarah daging) dalam kesehariannya.

Program pemanfaatan minyak jelantah dilakukan: 1) minyak jelantah dikumpulkan kemudian dijual ke pembeli minyak jelantah untuk menjadi bahan biodiesel, 2) untuk dibuat sabun dari minyak jelantah, 3) dibuat lilin hias.

Menumbuhkan kesadaran masyarakat memang tidak mudah. Untuk itu dibutuhkan program topdown maupun bottom-up serta kegigihan yang terus menerus dari para pemerhati lingkungan. Program ini dijalankan, dievaluasi dan dimonitor secara kontinu per bulan, sehingga akan didapat kendala dan hasil yang diharapkan. 


\section{METODE PELAKSANAAN PKM}

Kegiatan yang dilakukan oleh Tim PKM secara garis besar sebagai berikut: Tahap 1, adalah persiapan pembentukan Tim dan pembuatan proposal yang akan diajukan ke LPKM Universitas Tarumanagara sebagai pemberi dana. Tim PPM sendiri sebagai pelaksana tugas PPM dalam pembuatan program Pemanfaatan Limbah Minyak Jelantah serta pendampingan pelaksanaannya; Tahap 2, Survei lapangan ke lokasi RW 11 Kelurahan Pekayon Jaya, Kecamatan Bekasi Selatan, Kota Bekasi serta mendata hal-hal yang diperlukan; Tahap 3, Pembuatan program secara terencana dan terukur berdasarkan data lapangan dan literatur; Tahap 4, Pelaksanaan program Pemanfaatan Limbah Minyak Jelantah; Tahap 5, Monitoring dan Evaluasi Tahap 1 Pelaksanaan program Pemanfaatan Limbah Minyak Jelantah; Tahap 6, Monitoring dan Evaluasi Tahap 2 Pelaksanaan program Pemanfaatan Limbah Minyak Jelantah; Tahap 7, Tahap Pembuatan laporan.

\section{HASIL DAN PEMBAHASAN}

\subsection{Program Jelantahisasi (Pemanfaatan Minyak Jelantah)}

Program "jelantahisasi" adalah program pemanfaatan minyak jelantah agar lebih berdaya guna baik dari aspek lingkungan dan ekonomi berbasis komunitas masyarakat. Minyak jelantah adalah minyak bekas pakai dari konsumsi menggoreng untuk kegiatan dapur (memasak) yang biasanya dibuang. Pembuangan minyak jelantah ini (karena benda cair) maka biasanya dibuang di saluran air bersama air buangan lainnya. Namun sifat dari minyak sendiri tidak dapat menyatu dengan air serta pada suhu yang relatif rendah maka akan menggumpal. Tanpa disadari, minyak jelantah ini akan mencemari lingkungan dan saluran air karena akan menyumbat saluran.

Warga RW 11 beserta Tim PKM Untar mengadakan kerja sama untuk mengatasi pencemaran lingkungan melalui program jelantahisasi. Program ini melibatkan seluruh warga RW 11 yang terdiri dari 4 RT. Peran aparat (pengurus) RT dan RW sangatlah penting. Pengurus menggerakkan warganya melalui pertemuan-pertemuan rutin agar warga tergerak untuk melakukan aksi lingkungan secara menerus hingga menjadi "habit" atau menjadi kebiasaannya.

Jelantahisasi ini dilaksanakan dengan sistem top-down maupun bottom-up, artinya inisiasi pelaksanaan dengan surat perintah dari RW ke RT kemudian dari RT ke warganya. Sedangkan pengumpulan dengan sistem bottom-up, artinya warga mengumpulkan minyak jelantah ke RT kemudian dari RT ke RW. Namun sesungguhnya, warga adalah nasabah minyak jelantah. Warga sebagai nasabah minyak jelantah dengan menabung (mengumpulkan) minyak jelantah yang nantinya dapat diuangkan. Semua hasil dari volume minyak jelantah yang dikumpulkan warga dicatat dengan catatan yang dapat dipertanggungjawabkan seperti di perbankan.

\subsection{Pengertian Minyak Jelantah dan Jelantahisasi}

Minyak jelantah adalah minyak goreng yang telah dipakai beberapa kali. Minyak jelantah ini karena sudah dipanaskan beberapa kali dalam pemakaian maka kualitasnya sudah tidak baik, bahkan bahaya bagi tubuh bila dipakai lagi. Selain dari senyawa kimia yang sudah rusak, juga adanya bakteri dan mengandung unsur radikal bebas yang menyebabkan penyakit kanker. Radikal bebas akan masuk ke tubuh bersama makanan kemudian menyerang sel-sel tubuh. Jelantah mengandung asam lemak jenuh tinggi dikarenakan proses pemanasan. Ini bila dikonsumsi akan mengakibatkan penyakit kolesterol tinggi dalam darah. Kolesterol tinggi ini menjadikan berbagai penyakit diantaranya jantung, penyempitan pembuluh darah hingga stok yang bisa berakhir pada kematian.

Namun sesungguhnya minyak jelantah ini masih bisa dimanfaatkan untuk dipakai sebagai biodiesel, sabun cuci dan lilin aroma terapi. Inilah yang disebut jelantahisasi. Pengertian 
jelantahisasi adalah program pemanfaatan minyak jelantah oleh masyarakat sebagai bentuk lain (seperti biodiesel, sabun dan lilin) agar minyak jelantah tidak dikonsumsi untuk makanan dan tidak dibuang sembarangan (tidak mencemari lingkungan). Jelantahisasi ini adalah gerakan bersama pada masyarakat untuk peduli lingkungan dan peningkatan ekonomi melalui pengumpulan minyak jelantah dan pengolahannya baik melalui bank MIJEL ataupun pengolahan bentuk sabun dan lilin.

\subsection{Dampak Minyak Jelantah Pada Lingkungan}

Minyak jelantah hasil limbah rumah tangga ataupun bisnis makanan berskala kecil biasanya tidak dimanfaatkan bahkan dibuang di saluran alir. Limbah ini sangat berbahaya karena memberikan dampak matinya biota-biota air yang seharusnya hidup di perairan. Hal ini seolah-olah permasalahan sederhana dan sepele bila manusia membuang beberapa mililiter minyak di saluran air. Namun sesungguhnya semua akan bermuara pada rusaknya lingkungan.

Bermula pada tindakan manusia membuang minyak jelantah ke saluran atau ke tanah, minyak ini akan menyumbat saluran air kemudian mencemari air dan tanah. Lapisan minyak menutupi permukaan air sehingga ekosistem air akan terganggu. Minyak jelantah ini akan meracuni tanaman dan hewan. Minyak jelantah yang dibuang di air atau di tanah akan sulit diurai oleh mikroorganisme tanah sehingga air dan tanah tercemar.

\subsection{Minyak Jelantah Untuk Biodiesel}

Pemanfaatan minyak jelantah dapat sebagai alternatif bahan baku biodiesel. Biodiesel ini akan mengurangi 91,7\% emisi CO2 dibandingkan bila memakai bahan baku solar (Tim Publikasi Katadata, 2020). Bahkan minyak jelantah ini berpotensi untuk menyumbangkan $32 \%$ produksi biodiesel nasional. Biodiesel merupakan bahan bakar nabati yang dipakai sebagai bahan bakar alternatif mesin diesel. Sebelum pemanfaatan minyak jelantah sebagai bahan baku alternatif biodiesel, biodiesel memakai bahan baku minyak sawit mentah. Pada wilayah-wilayah yang tidak terjangkau listrik, pemakaian diesel dengan bahan baku minyak sawit mentah ini dipakai, namun bila dikalkulasi maka termasuk ini ber-cost tinggi. Oleh karena itu, alternatif bahan baku diperlukan sebagai pengganti minyak sawit mentah. Minyak jelantah sebagai alternatif penggantinya dapat digolongkan sebagai sumber energi yang sustain (berkelanjutan) karena minyak jelantah dapat diubah menjadi bahan bakar biodiesel yang aman terhadap lingkungan (dengan polusi udara yang jauh lebih sedikit dibandingkan dengan bahan bakar solar). Minyak jelantah sebagai bahan baku untuk biodiesel dapat menurunkan emisi karbon. Ini juga akan mengurangi emisi gas rumah kaca. Pemakaian minyak jelantah sebagai bahan baku alternatif biodiesel ini merupakan cara tepat untuk ketahanan energi nasional, menyelamatkan lingkungan serta mengalihkan penggunaan bahan bakar dari fosil ke bahan bakar yang berkelanjutan (Purnama, 2021).

\subsection{Minyak Jelantah Untuk Sabun}

Di samping manfaat minyak jelantah sebagai bahan baku alternatif biodiesel, minyak jelantah juga bisa diolah menjadi sabun cuci. Pembuatan sabun cuci ini mengalami proses yang sederhana namun berdaya guna tinggi mengingat pemanfaatan minyak jelantah ini sebagai program penyelamat lingkungan. Langkah-langkah diperlukan dalam pembuatan sabun cuci dari minyak jelantah ini, mulai dari penjernihan dan penghilangan bau bekas makanan. Proses ini memakai arang, Arang sebagai bahan pengikat bau serta penjernih minyak jelantah. Proses ini sangat penting dan memakan waktu 24 jam dengan cara pengendapan, penyaringan penghilankan bau serta penjernihan minyak jelantah. Proses selanjutnya adalah pembuatan sabun cuci dengan $\mathrm{NaOH}$ atau soda api serta memberikan aroma, warna dan pencetakan. Selanjutnya adalah proses pengeringan yang memerlukan waktu 2 hari serta finishing atau pengemasan (Srihandi, 2017). 


\subsection{Minyak Jelantah Untuk Lilin}

Di samping minyak jelantah dimanfaatkan sebagai bahan alternatif biodiesel dan sabun cuci, jelantah juga bisa dipakai untuk pembuatan lilin. Lilin ini dapat diberi essen dengan essen aroma terapi sehingga lebih wangi, harum dan diminati. Pembuat lilin dari jelantah ini tentunya jelantah harus di proses penjernihan dulu agar hasilnya bagus dan diproses penghilangan bau dari bekas masakan gorengan. Setelah bau hilang dan minyak jernih, barulah dilakukan proses pembuatan lilin dengan campuran parafin, essential oil dan pewarna. Pewarna yang dipakai adalah dari bubuk pastel (alat gambar) yang sudah tidak terpakai atau denga minyak pewarna lainnya. Pastel warna diserut lebih dahulu sebagai campuran untuk memberi warna lilin. Lilin dicetak di gelas kaca agar terlihat cantik.

\subsection{Pemanfaatan Limbah Jelantah Sebagai Program Pengembangan Produk UMKM Di Wilayah} Kampung Kota -RW 11 Pekayon Jaya, Bekasi Selatan.

RW 11 terletak di jantungnya kota Bekasi. Bila dilihat dari geografisnya, RW 11 Pekayon Jaya terletak di pusat administrasi Bekasi. RW 11 dengan membawahi 4 RT berpenduduk sekitar 550 orang sangat berpotensi bila dilakukan jelantahisasi. Tentunya ini akan menghasilkan limbah jelantah yang tidak sedikit. Kemana mereka akan buang? Dari sinilah, ide jelantahisasi menjadi hal penting untuk dilakukan sebagai program lingkungan oleh RW 11 bekerja sama dengan PKM UNTAR dalam memanfaatkan minyak jelantah ini.

Awalnya sebagian warga RW 11 sudah melakukan pengumpulan minyak jelantah, namun aksi ini kurang masih karena baru dilakukan secara parsial oleh sebagian warga. Pada PKM UNTAR ini, kegiatan jelantahisasi dilakukan secara terstuktur dan terencana dari RW ke RT kemudian seluruh warga dari masing-masing RT. Sistem pengumpulan dilakukan dengan cara Bank MIJEL atau tabungan dengan menyerahkan minyak jelantah (dicatat sebagai tabungan nasabah warga). Sehingga tiap warga menjadi nasabah dari bank MIJEL.

RW 11 melaksanakan kegiatan jelantahisasi dimulai dengan pengumpulan minyak jelantah. Untuk memberikan semangat pada warga RW, maka setiap warga diberikan jerigen 1 lt sebagai tempat pengumpulan minyak jelantah dari dapur masing-masing. Setelah minyak jelantah dikumpulkan masing-masing oleh warga, maka per minggu jam 10 jelantah diambil petugas untuk diukur volumenya dan dicatat di buku tabungan sebagai tabungan minyak jelantah yang bisa diuangkan nantinya. Setelah pengambilan dari masing-masing warga, minyak jelantah akan ditampung di petugas RT di jerigen besar yang kemudian diserahkan ke petugas RW dengan pencatatannya. Setelah terkumpul semua minyak jelantah akan dijual ke pembeli minyak jelantah. Harga minyak jelantah ini bervariasi berkisar antara Rp 5.000-Rp 7.000 per liter. Hasil penjualan minyak jelantah ini kemudian dikembalikan dari RW ke RT selanjutnya diteruskan ke warga. Namun karena program ini berupa tabungan, maka uang penjualan disimpan di RT masing-masing hingga pada jumlah tertentu dapat diambil. Beberapa opsi ditawarkan ke warga yaitu: tabungan bank MIJEL; sedekah MIJEL atau barter barang dengan MIJEL. Intinya adalah warga berpartisipasi aktif dalam program lingkungan.

Di samping program bank MIJEL, Tim PKM juga memberikan mediasi pelatihan pembuatan produk sabun cuci oleh pakar lingkungan Bapak Dony Pradana. Pelatihan ini dilakukan beberapa kali di lingkungan RT-RT di RW 11. Pada masa pandemi ini, pelaksanaan pelatihan dilakukan di lapangan RT 2. Pelatihan diikuti sebagian warga RT bersamaan dengan acara arisan warga. Di saat pandemi seperti sekarang ini, pemanfaatan ruang terbuka hijau sebagai tempat berkumpul warga 
baik untuk olahraga maupun kegiatan sebagai arisan dan bertanam sayuran. Warga RW 11 sudah melakukan kegiatan terkait lingkungan hidup secara aktif.

Di samping jelantah sebagai bahan baku biodiesel dan sabun, minyak jelantah juga dapat dimanfaatkan sebagai lilin. Lilin dengan aroma terapi dan diberi warna yang menarik akam meningkatkan minat warga untuk menjadi nasabah MIJEL. Di samping menyelamatkan lingkungan, produk lilin ini juga bernilai ekonomis.

Dokumentasi kegiatan PKM dapat dilihat pada Gambar 2 s/d Gambar 7.

\section{Gambar 2}

Pengadaan Jerigen untuk Program Jelantahisasi (Pemanfaatan Minyak Jelantah) di RW 11

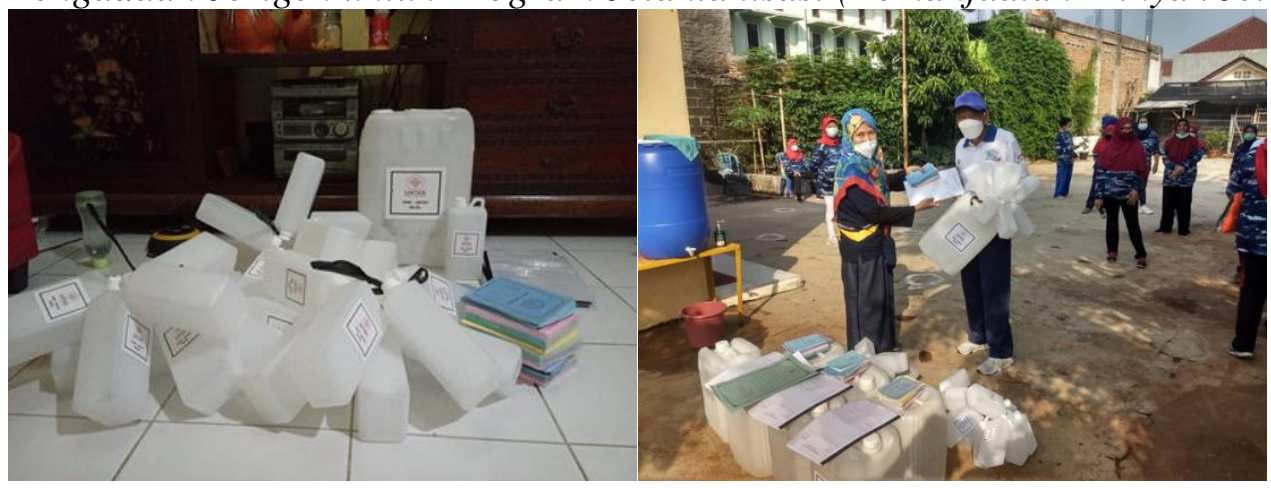

\section{Gambar 3}

Pengumpulan Minyak Jelantah di Ketua RW 11 Sebelum Dijual ke Pembeli

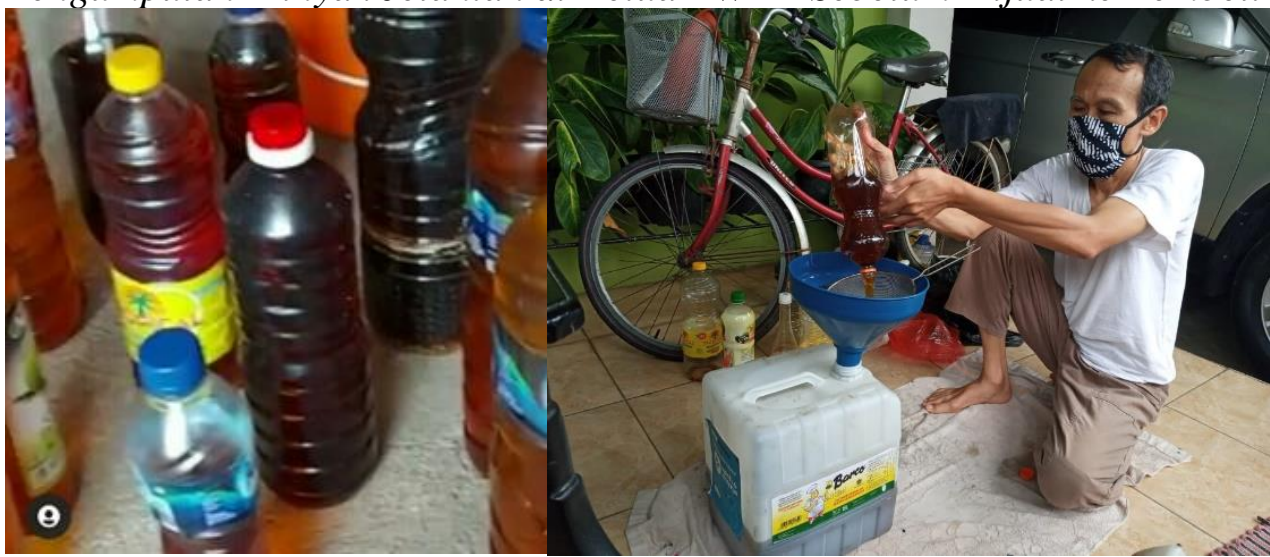

\section{Gambar 4}

Hasil Sabun dari Minyak Jelantah

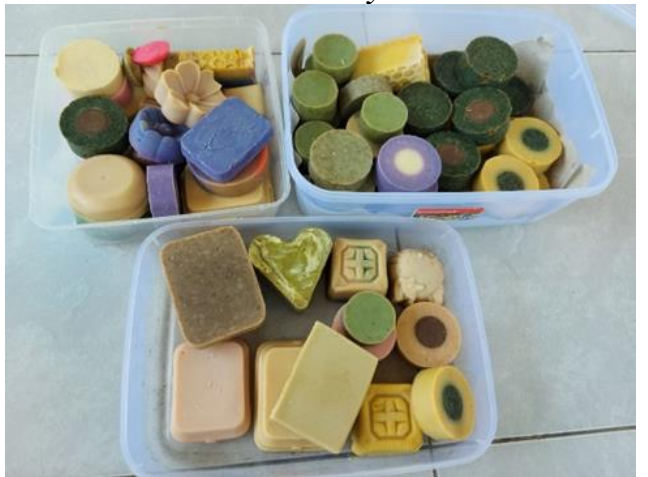




\section{Gambar 5}

\section{Proses Pembuatan Lilin Aroma Terapi dari Minyak Jelantah}
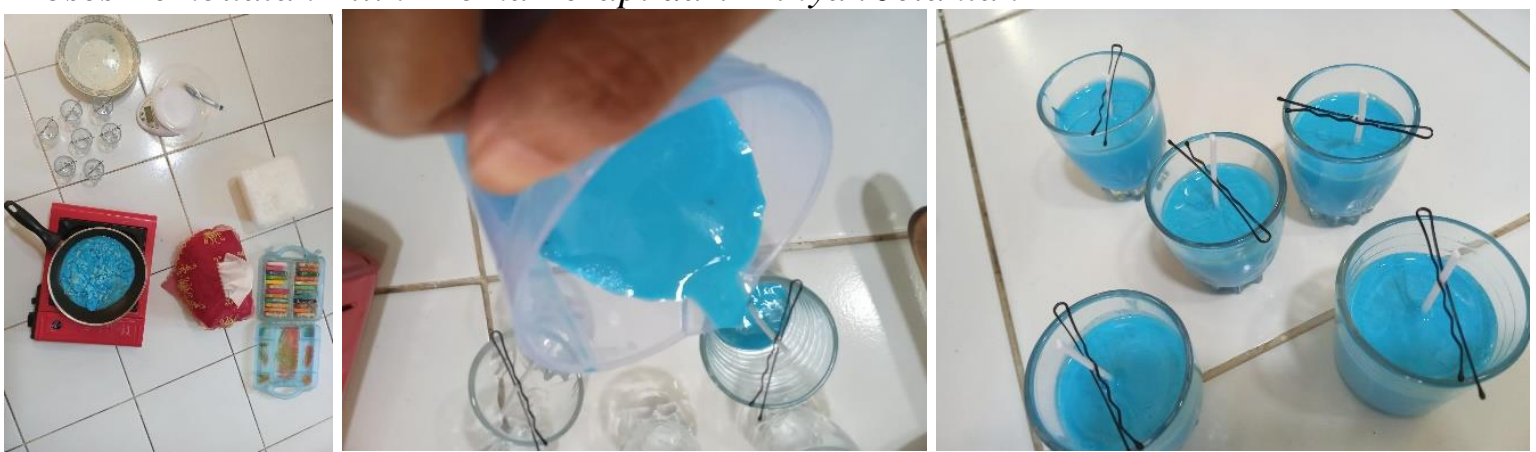

\section{Gambar 6}

Sosialisasi Jelantahisasi dan Praktek Pembuatan Sabun dari Minyak Jelantah

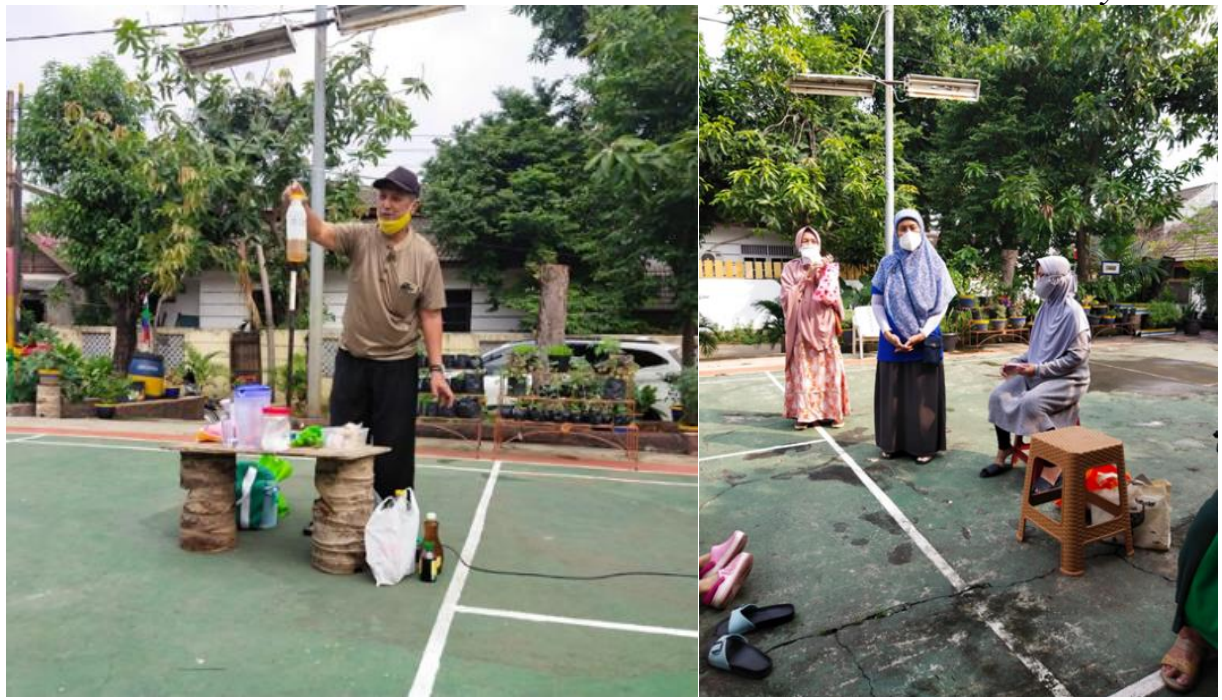

\section{Gambar 7}

Sosialisasi dan Serah Terima Program Jelantahisasi untuk dilaksanakan di RW 11

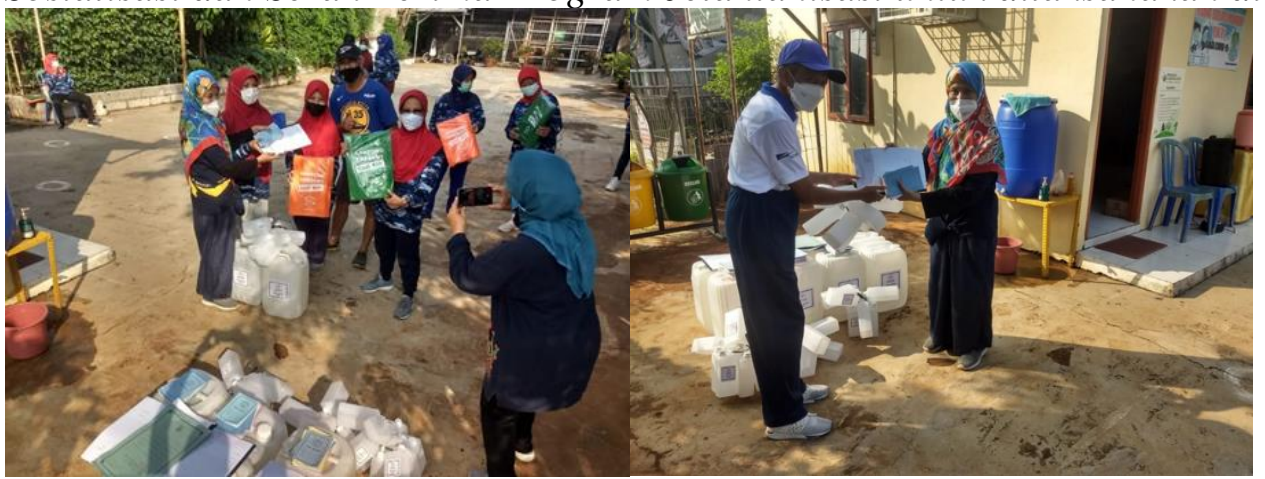

\section{KESIMPULAN DAN SARAN}

Program ini merupakan program terkait keselamatan lingkungan dari pencemaran serta pemberdayaan ekonomi masyarakat melalui pemanfaatan minyak jelantah. Minyak jelantah dapat dimanfaatkan sebagai bahan dasar biodiesel, sabun maupun lilin. Kesadaran masyarakat tentang bahayanya minyak jelantah pada pencemaran lingkungan harus selalu dikampanyekan secara terus menerus hingga menjadi habit bagi warna RW 11. Sekelompok warga yang tergabung dalam 
pecinta lingkungan sesungguhnya sudah berupaya untuk selalu mengingatkan warga agar memilah sampah dan memanfaatkan sampah agar berkurang volume sampah yang dibuang di TPA karena bisa dimanfaatkan untuk bermacam-macam kegunaan, salah satunya adalah limbah jelantah.

Program PKM ini melibatkan semua warga RW 11 beserta pengurus RW dan RT yang berperan aktif untuk mendorong warganya mengikuti program ini. Bank MIJEL (Bank Minyak Jelantah) diarahkan agar warga sadar lingkungan serta mendapatkan manfaat dari keikutsertaan pengumpulan dan pengolahan MIJEL ini.

Tentu dalam pelaksanaan terjadi kendala di lapangan dikarenakan pemahaman dan motivasi tiap warga berbeda. Namun tim berharap dengan peran dari top-down artinya dari pengurus RW dan RT yang menjadikan program ini sebagai program RW-RT maka semakin banyak warga yang terlibat. Semakin banyak warga yang terlibat dalam program lingkungan akan menjadikan lingkungan semakin bersih, sehat dan ekonomi masyarakat terbantu melalui UMKM.

Ucapan Terima Kasih (Acknowledgement)

Terimakasih kami ucapkan kepada LPPM Universitas Tarumanagara yang telah memberikan dana untuk program PKM ini.

\section{DAFTAR PUSTAKA}

Angie, B. (2019). Awas, ini 5 bahaya pengguna minyak jelantah pada tubuh. IDN Times. https://www.idntimes.com/food/dining-guide/birgitta-angie/bahaya-minyak-jelantah-bagitubuh/5.

Bidilah, S., Rumape, O., \& Erni, M. (Februari 2017). Optimasi waktu pengadukan dan volume KOH Sabun cair berbahan dasar minyak jelantah. Jurnal Entropi 12(1), 55-60.

Purnama, S. (2021). Jangan buang minyak jelantah sembarangan. Antara News. https://www.antaranews.com/berita/2202854/jangan-buang-minyak-jelantah-sembarangan.

Riyanta, A. \& Nurniswati. (Februari 2017). Adsorpsi minyak jelantah menggunakan karbon aktif dan serbuk kopi pada pembuatan sabun padat ramah lingkungan, Jurnal Entropi 12(1).

Thadeus, M. S. (2015). Dampak konsumsi minyak jelantah terhadap oksidatif DNA (kajian aspek: biologi molekuler dan imunologi). Disertasi Ilmu Kedokteran dan Kesehatan Fakultas Kedokteran UGM, Yogyakarta. https://fk.ugm.ac.id/bahaya-minyak-jelantah/

Srihandi, G. (2017). Membuat sabun dari jelantah. Sahabat Alam Cilik. https://sahabatalamcilik.weebly.com/do-it-your-self/membuat-sabun-dari-jelantah

Tim Publikasi Katadata. (2020). Minyak jelantah, dari limbah jadi biodiesel. Katadata. https://katadata.co.id/timpublikasikatadata/infografik/5f10547778388/minyak-jelantahdari-limbah-jadi-biodiesel 